\title{
CONGENITAL PYLORIC STENOSIS AN INVESTIGATION OF 578 CASES
}

BY

\author{
BRIAN MACMAHON,* R. G. RECORD, and THOMAS MCKEOWN \\ From the Department of Social Medicine, University of Birmingham
}

For investigation of certain aspects of the aetiology of the congenital malformations we require information about

(a) a representative collection of affected individuals,

(b) the population of births from which the malformed individuals are drawn.

In the case of pyloric stenosis, the collection of this information now raises no insuperable difficulty, and if knowledge (of such matters as the association of the malformation with maternal age and birth rank) is still incomplete, it is because inquiries have usually been based on hospital births for which the population of related births is unknown. In the present investigation we have attempted to overcome this difficulty by the following methods:

(1) A series of Birmingham children with pyloric stenosis has been assembled by examination of the records of all Birmingham hospitals which admit children, for the 10-year period 1940-49. $\dagger$ (It was, of course, necessary to exclude children whose homes were not in Birmingham.) The series can be regarded as complete in so far as

(i) the malformation comes to medical attention and is correctly diagnosed,

(ii) patients affected are sent into hospital.

(2) The related population of births is the total Birmingham births of the same period, from which we have some information from central sources. But we were also fortunate in having previously investigated a sample (every 200th birth) for comparison with malformations of the central nervous system, and it was only necessary to extend this sample to cover a further two years (1948-49).

Table I (overleaf) shows how diagnosis was confirmed in the 578 cases included in the series. In 93 per cent. the pylorus was inspected at operation or autopsy; 7 per cent. were accepted on medical evidence only (the presence of a palpable pyloric tumour). Insistence on these criteria entailed exclusion of 49 cases, shown in hospital records as " pyloric stenosis" or " pylorospasm ", in which a tumour was neither seen nor palpated.

* In receipt of a personal grant from the Medical Research Council.

$\dagger 86.5$ per cent. were treated at the Birmingham Children's Hospital, and the remainder were distributed between five other hospitals. 
TABLE I

Methods of Confirmation of Diagnosis of Congenital Pyloric Stenosis

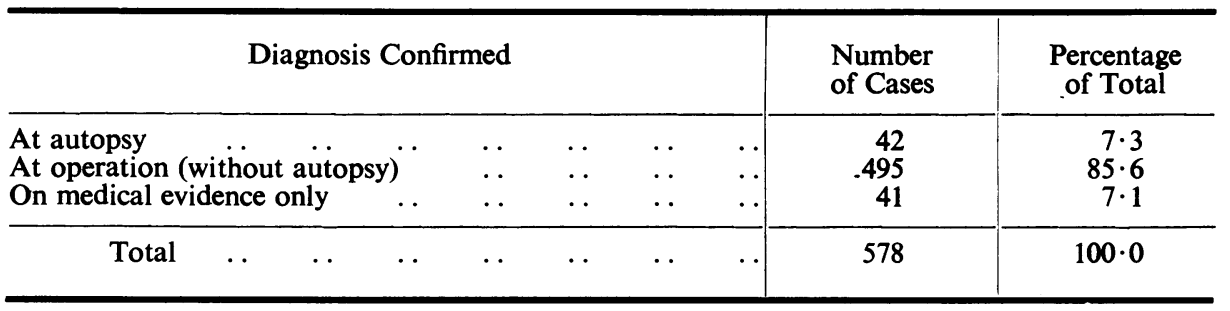

For all 578 individuals certain observations were available in the hospital documents. Other information was elicited by field inquiry, in which one of us (B.M.) successfully traced 489 patients ( 85 per cent.). The interview in the home was with the mother (428), father (21), maternal grandmother (30), or a more distant relative (10).

In the present communication we rely mainly on the material obtained from hospital records, and since we make no use of the control series we postpone comment on it.

\section{A. ObSERVATIONS from Hospital Records}

(1) INCIDENCE.-Before considering evidence on the incidence of pyloric stenosis we should note that the series does not include:

(a) Patients diagnosed and treated at home or in a nursing home. The number is unknown but is thought to be small.

(b) Patients in whom the diagnosis is not established (using criteria in Table I).

Thus cases of pylorospasm and of "pyloric stenosis" (treated medically) in which no tumour was palpated are excluded. This must result in omission of a few individuals in whom the malformation is present (though unconfirmed).

It is also possible that a few Birmingham children were treated in hospitals outside the city, but on the other hand Birmingham attracts cases from the whole Midland Region, and we are satisfied that the number of Birmingham patients who seek treatment outside the city is negligible (except perhaps in the early war years when evacuation was common).

Table II gives the incidence of the condition in Birmingham for the 10 years 1940-49 as 2.98 per thousand live births. The figure, which is by no means constant from year to year, is lowest in $1941(2 \cdot 1)$ and highest in $1949(4 \cdot 2)$, and has certainly increased during the past few years. But we cannot safely conclude that the actual incidence of the condition has increased, for there were considerable movements of population during the early war years, and since 1945 improved medical services may have resulted in more complete ascertainment of cases.

Our figure for the 10-year period (2.98 per thousand live births) is not much different from the 2.8 given by Davison (1946) for Newcastle-on-Tyne from a series of 49 cases. A higher figure (4.0) obtained by Wallgren (1941) from 102 
cases in Göteborg is nearer our estimate for the last few years, and it seems reasonable to give the present incidence of the diagnosed condition as about 4 per thousand live births, while reserving judgment on the secular trend.

TABLE II

Incidence of Congenital Pyloric Stenosis

\begin{tabular}{c|c|cc}
\hline & Number of Cases & Related Live Births & $\begin{array}{c}\text { Incidence per 1,000 } \\
\text { Live Births }\end{array}$ \\
\hline 1940 & 51 & 15,882 & $3 \cdot 2$ \\
1941 & 29 & 14,063 & $2 \cdot 1$ \\
1942 & 45 & 17,657 & $2 \cdot 5$ \\
1943 & 42 & 19,376 & $2 \cdot 2$ \\
1944 & 51 & 21,720 & $2 \cdot 3$ \\
1945 & 60 & 19,185 & $3 \cdot 1$ \\
1946 & 70 & 22,134 & $3 \cdot 2$ \\
1947 & 75 & 24,000 & $3 \cdot 1$ \\
1948 & 72 & 20,530 & $3 \cdot 5$ \\
1949 & 83 & 19,669 & $4 \cdot 2$ \\
\hline Total & 578 & 194,216 & $2 \cdot 98$ \\
\hline
\end{tabular}

(2) Sex Ratio.-Table III gives the sex ratio (per cent. male) of the 578 individuals as $81 \cdot 7$, and the sex incidence (per thousand related live births) as 4.73 for males and $1 \cdot 12$ for females. In calculating sex incidence, numbers of related live births of each sex have been obtained by applying the sex ratio of Birmingham births (taken from the Registrar-General's Statistics for 1940-1948) to the local authority's figure for the number of live births of both sexes.

There has, of course, been no serious doubt about the sex ratio in congenital pyloric stenosis. Fairly consistent figures are given, for example, by Monrad (1927), Thompson and Gaisford (1935), Akin and Forbes (1947), Nafe (1947), Schaefer and Erbes (1948), and Ward-McQuaid and Porritt (1950). Taken together, these reports include 1,061 cases of which 83.7 per cent. are males. This is in close accord with our own observation.

TABLE III

Sex InCidence of Pyloric Stenosis

\begin{tabular}{|c|c|c|c|c|c|}
\hline Sex & $\begin{array}{l}\text { Related Live } \\
\text { Births }\end{array}$ & $\begin{array}{l}\text { Number of } \\
\text { Cases }\end{array}$ & $\begin{array}{l}\text { Incidence per } \\
\text { 1,000 Live } \\
\text { Births }\end{array}$ & Relative Risk & $\begin{array}{l}\text { Sex Ratio } \\
\text { (\% Male) }\end{array}$ \\
\hline $\begin{array}{l}\text { Male } \\
\text { Female }\end{array}$ & $\begin{array}{l}99,875 \\
94,341\end{array}$ & $\begin{array}{l}472 \\
106\end{array}$ & $\begin{array}{l}4 \cdot 73 \\
1 \cdot 12\end{array}$ & $\begin{array}{l}4 \cdot 45 \\
1 \cdot 00\end{array}$ & $81 \cdot 7$ \\
\hline
\end{tabular}

Numbers of related live births were estimated for males and females by applying the sex ratio calculated from the Registrar-General's statistics for Birmingham, 1940-48, to the number of related live births $(194,216)$. 
(3) OTHER MALFORMATIONS EXHIBITED BY AFFECTED INDIVIDUALS.-A list of other malformations exhibited by 578 affected individuals is given in Table IV. It is difficult to interpret this evidence, since no child could be entered in Table IV unless it survived to the age at which pyloric stenosis is diagnosed. For example, the association of pyloric stenosis with anencephalus (which invariably results in early death) is ruled out, and its association with spina bifida and hydrocephalus (which often result in early death) is made less likely. Attention must therefore be confined to the less lethal malformations manifested at an early age whose exhibition is compatible with survival for a considerable period after birth. Unfortunately it is for such malformations that our knowledge of incidence is most sketchy.

TABLE IV

Other Malformations exhibited by 578 Infants with Pyloric Stenosis

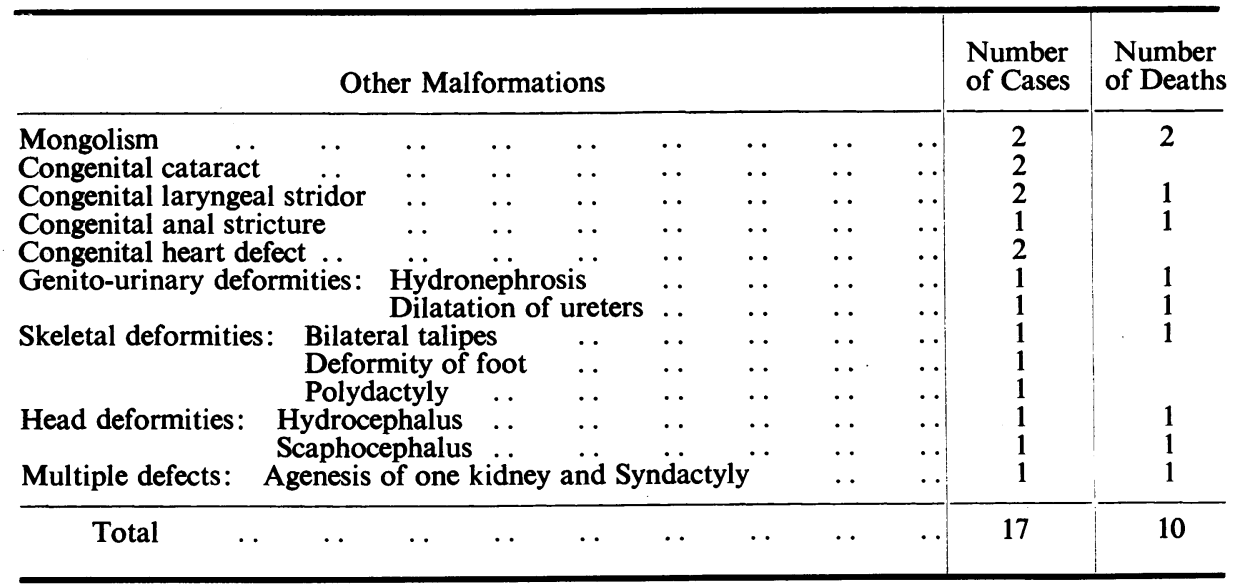

Seventeen individuals ( 2.9 per cent.) exhibited other malformations, and ten of them died before the first birthday. Four others (not entered in Table IV) were mentally retarded (one a spastic with a cerebral defect), and a fifth (twin of an individual also affected by pyloric stenosis) died of a strangulated hernia. Although we have no figures for comparison, it seems justifiable to conclude that there is no striking increase in the incidence of other malformations (all types) in individuals affected by pyloric stenosis, and that there is no obvious association between pyloric stenosis and any particular malformation.

Other malformations associated with pyloric stenosis are reported by Thomson (1921), Still (1927), Rinvik (1940), Cockayne and Penrose (1943), Akin and Forbes (1947), and Grimes and others (1950). Taken together, these series include 1,124 patients of whom $30(2 \cdot 7$ per cent.) had other malformations.

(4) Economic Status of Parents.-Our only information directly related to the economic circumstances of parents is the locality of domicile. The home address of each patient was located by ward, and wards were classified in three groups whose constitution has previously been described (Record and McKeown, 1949, 
Appendix A). It will suffice to state here that in general the poorest homes are in Group I, the best in Group III.

Table $\mathrm{V}$ compares the distribution between these groups, of homes of malformed propositi and of related live births. There is no evidence that the condition is associated with economic circumstances, although having regard to the known relation between the incidence of pyloric stenosis and parity, we must bear in mind the possible effect of differences in the parity structure of the populations of births in the three ward groups. A later communication will consider the association of incidence with birth rank, but we may state now that a correction for parity does not alter the conclusion stated above.

TABLE V

Distribution by Ward Group of all Cases of Pyloric Stenosis and of Related Live Births

\begin{tabular}{|c|c|c|c|c|c|c|}
\hline \multirow{2}{*}{ Ward Group } & \multicolumn{2}{|c|}{ All Propositi } & \multicolumn{2}{|c|}{ Related Live Births } & \multirow{2}{*}{$\begin{array}{l}\text { Difference } \\
(a)-(b)\end{array}$} & \multirow{2}{*}{$\begin{array}{l}\text { Incidence per } \\
\text { 1,000 Live } \\
\text { Births }\end{array}$} \\
\hline & Number & $\begin{array}{l}\text { Percentage } \\
\quad(a)\end{array}$ & Number & $\begin{array}{l}\text { Percentage } \\
(b)\end{array}$ & & \\
\hline $\begin{array}{c}1 \\
2 \\
3 \\
\text { Unlocated }\end{array}$ & $\begin{array}{l}216 \\
241 \\
121 \\
-\end{array}$ & $\begin{array}{c}37 \cdot 37 \\
41 \cdot 70 \\
20 \cdot 93 \\
-\end{array}$ & $\begin{array}{r}70,350 \\
87,243 \\
36,571 \\
52\end{array}$ & $\begin{array}{r}36 \cdot 22 \\
44 \cdot 92 \\
18 \cdot 83 \\
0 \cdot 03\end{array}$ & $\begin{array}{c}+1 \cdot 15 \pm 2 \cdot 00 \\
-3 \cdot 22 \pm 2 \cdot 07 \\
+2 \cdot 10 \pm 1 \cdot 63 \\
-\end{array}$ & $\begin{array}{c}3 \cdot 07 \\
2 \cdot 76 \\
3 \cdot 31 \\
-\end{array}$ \\
\hline All Wards & 578 & $100 \cdot 0$ & 194,216 & $100 \cdot 0$ & - & $2 \cdot 98$ \\
\hline
\end{tabular}

$\chi^{2}=2 \cdot 91, n=2,0 \cdot 2<P<0 \cdot 3$

In this context we may also consider briefly the question of legitimacy. Percentages of illegitimate births were as follows: for 578 malformations, 3.8 per cent. (estimated from hospital records); for 489 malformations visited at home, 3.7 per cent.; for related Birmingham live births (1940-48), 6.5 per cent. (RegistrarGeneral). We have no reason to stress a difference of this magnitude, but certainly there is no evidence that the incidence of pyloric stenosis is higher for illegitimate than for legitimate births.

(5) Seasonal Incidence.-The observation that the incidence of anencephalus is related to the season of birth and conception (McKeown and Record, 1951) makes it of interest to examine this possibility in the case of pyloric stenosis. The necessary data are given in Table VI (overleaf), which distributes the 578 cases by month and quarter of birth. Quarterly incidence of pyloric stenosis is compared with that of related live births, and provides no evidence of seasonal variation.

\section{B. ObSeRVATIONS ON INFORMation ObTAINEd by Field EnQuiry}

The observations so far discussed were available in hospital records, and are hence recorded for all 578 patients; the two remaining items of information (" maternal ill-health", and " subsequent history") were completed by field enquiry, and are known for only 489 individuals (born after 488 pregnancies). 
TABLE VI

Quarterly Distribution of Cases of Pyloric Stenosis

\begin{tabular}{|c|c|c|c|c|c|c|}
\hline \multirow{3}{*}{ Months } & \multicolumn{3}{|c|}{ Propositi } & \multicolumn{2}{|c|}{ Related Live Births } & \multirow{3}{*}{$\begin{array}{l}\text { Difference } \\
(a)-(b)\end{array}$} \\
\hline & \multicolumn{2}{|c|}{ Numbers } & \multirow{2}{*}{$\begin{array}{l}\text { Percentages } \\
\text { (a) }\end{array}$} & \multirow{2}{*}{ Numbers } & \multirow{2}{*}{$\begin{array}{l}\text { Percentages } \\
\text { (b) }\end{array}$} & \\
\hline & Months & Quarters & & & & \\
\hline $\begin{array}{l}\text { January } \\
\text { February } \\
\text { March }\end{array}$ & $\left.\begin{array}{l}49 \\
44 \\
57\end{array}\right\}$ & 150 & $25 \cdot 95$ & 48,855 & $25 \cdot 15$ & $+0 \cdot 80 \pm 1 \cdot 81$ \\
\hline $\begin{array}{l}\text { April } \\
\text { May } \\
\text { June }\end{array}$ & $\left.\begin{array}{l}64 \\
46 \\
39\end{array}\right\}$ & 149 & $25 \cdot 78$ & 50,496 & $26 \cdot 00$ & $-0 \cdot 22 \pm 1 \cdot 83$ \\
\hline $\begin{array}{l}\text { July } \\
\text { August } \\
\text { September }\end{array}$ & $\left.\begin{array}{l}39 \\
43 \\
51\end{array}\right\}$ & 133 & $23 \cdot 01$ & 48,070 & $24 \cdot 75$ & $-1 \cdot 74 \pm 1 \cdot 80$ \\
\hline $\begin{array}{l}\text { October } \\
\text { November } \\
\text { December }\end{array}$ & $\left.\begin{array}{l}46 \\
41 \\
59\end{array}\right\}$ & 146 & $25 \cdot 26$ & 46,795 & $24 \cdot 09$ & $+1 \cdot 17 \pm 1 \cdot 78$ \\
\hline Total & \multicolumn{2}{|c|}{578} & $100 \cdot 0$ & 194,216 & $100 \cdot 0$ & - \\
\hline
\end{tabular}

$\chi^{2}=1 \cdot 19, n=3,0 \cdot 7<P<0 \cdot 8$

TABLE VII

Major Causes of Maternal Ill-health during 488 Pregnancies

\begin{tabular}{|c|c|c|c|c|c|c|}
\hline \multirow[b]{2}{*}{ Trimester of Pregnancy } & \multicolumn{6}{|c|}{ Number of Mothers Affected by } \\
\hline & $\begin{array}{c}\text { Toxaemia } \\
\text { of } \\
\text { Pregnancy }\end{array}$ & $\begin{array}{l}\text { Hypereme- } \\
\text { sis }\end{array}$ & $\begin{array}{l}\text { Threatened } \\
\text { Abortion }\end{array}$ & $\begin{array}{c}\text { Emotional } \\
\text { Shock }\end{array}$ & $\begin{array}{l}\text { Falls and } \\
\text { Minor } \\
\text { Accidents }\end{array}$ & $\begin{array}{l}\text { Bacterial } \\
\text { and Viral } \\
\text { Disease }\end{array}$ \\
\hline $\begin{array}{c}1 \\
2 \\
3 \\
\text { Not limited to one trimester }\end{array}$ & $\begin{array}{r}0 \\
0 \\
21 \\
2\end{array}$ & $\begin{array}{r}0 \\
1 \\
0 \\
30\end{array}$ & $\begin{array}{r}13 \\
5 \\
1 \\
0\end{array}$ & $\begin{array}{l}5 \\
5 \\
4 \\
1\end{array}$ & $\begin{array}{r}3 \\
8 \\
21 \\
5\end{array}$ & $\begin{array}{r}6 \\
8 \\
16 \\
0\end{array}$ \\
\hline Total & 23 & 31 & 19 & 15 & 37 & 30 \\
\hline $\begin{array}{c}\text { Percent of } 488 \text { pregnancies } \\
\text { affected } \ldots\end{array}$ & $4 \cdot 7$ & $6 \cdot 4$ & $3 \cdot 9$ & $3 \cdot 1$ & $7 \cdot 6$ & $6 \cdot 1$ \\
\hline
\end{tabular}

(1) Maternal Ill-health during Pregnancy.-Table VII gives the incidence of major causes of maternal ill-health during pregnancy,* and Table VIII provides more detail for the bacterial and viral diseases grouped in Table VII. No disease appears with undue frequency; and no instance of rubella was recorded (this was the subject of a specific question). In the absence of further evidence, and of

* The diagnosis of illness in all cases rests solely on the mother's statement, and is on this account inevitably open to doubt. 
TABLE VIII

Bacterial and Viral Illnesses during Pregnancy

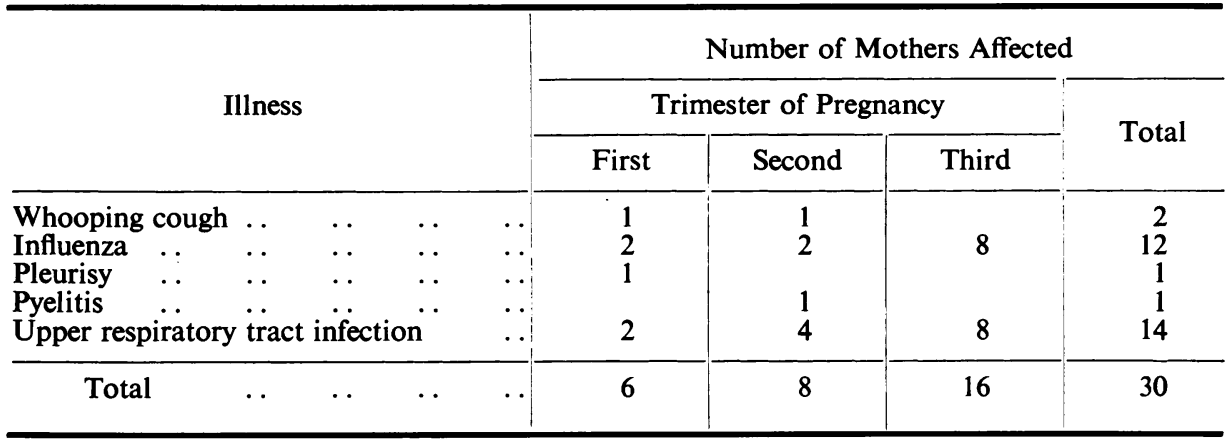

similar information about a control series recorded by the same observer, we attach no significance to the rather large number of falls and minor accidents reported in the third trimester. There are three other cases of interest not included in the Table: one mother attempted to procure an abortion by taking drugs, and two had positive Wassermann reactions during pregnancy.

(2) LATER HISTORY.- - History of later symptoms has been recorded by field enquiry in view of reports that after treatment for pyloric stenosis vomiting occasionally persists for periods up to 3 years (Monrad, 1927), and that radiological evidence of the disease may be elicited in most cases even later (Wallgren, 1937; Runström, 1939; Andresen, 1940). In seven patients vomiting had persisted after discharge from hospital, in two of them as late as the third year. Two patients were vomiting daily at the time of the visit. No case was seen in which vomiting continued after the third birthday (although many patients had not, of course, reached this age at the time of the enquiry).

Ten patients were admitted to hospital because of gastro-enteritis, and two of them died as a result of this illness. The incidence of this condition is probably not higher than in the general population of births.

\section{SUMMARY}

An attempt has been made to collect information about every diagnosed case of pyloric stenosis born in the period 1940-49, and domiciled in Birmingham.

A. Observations based on hospital records (578 individuals).

(i) The incidence of diagnosed cases in Birmingham during the ten years was 2.98 per thousand live births, and during the last two years examined (1948-49) about 4 per thousand.

(ii) The sex ratio (per cent. male) was $81 \cdot 7$, and the sex incidence (per thousand related live births of the same sex) $4 \cdot 73$ for males, and $1 \cdot 12$ for females.

(iii) There was no evidence of increased incidence of other malformations (all types) in affected children, or of association between pyloric stenosis and any particular malformation. 
192 BRIAN MacMAHON, R. G. RECORD, AND THOMAS McKEOWN

Incidence was unrelated to:

(iv) economic circumstances of the parents (as indicated by locality of domicile)

(v) legitimacy of birth

(vi) season of birth.

B. Observations recorded by field enquiry (489 individuals).

(i) No history of rubella was elicited, and no other disease was reported with undue frequency in pregnancies which preceded births of children with pyloric stenosis.

(ii) In seven of the patients visited at home, vomiting had persisted after discharge from hospital (in two cases as late as the third year).

We are greatly indebted to the Birmingham Institute of Child Health, and to the staff of the Birmingham Children's Hospital, for permitting us to use their records. We are also grateful to the staffs of other Birmingham hospitals, in particular Dudley Road and Selly Oak, who gave access to their records.

\section{REFERENCES}

Akin, J. T., and Forbes, G. B. (1947). Surgery, 21, 512.

Andresen, K. (1940). Acta paediatr., Stockh., 27, 334.

Cockayne, E. A., and Penrose, L. S. (1943). Ohio J. Sci., 43, 1.

Davison, G. (1946). Arch. Dis. Childh., 21, 113.

Grimes, O. F.. Bell, H. G., and Olney, M. B. (1950). J. Pediat., 37, 522.

McKeown, T., and Record, R. G. (1951). Lancet, 1, 192.

Monrad (1927). Mschr. Kinderheilk., 37, 473.

Nafe, C. A. (1947). Arch. Surg., Chicago, 54, 555.

Record, R. G., and McKeown, T. (1949). British Journal of Social Medicine, 3, 183.

Rinvik, R. (1940). Acta paediatr., Stockh., 27, 298.

Runström, G. (1939). Acta paediatr., Stockh., 26, 383.

Schaefer, A. A., and Erbes, J. (1948). Surg. Gynec. Obstet., 86, 45.

Still, G. F. (1927). Lancet, 2, 795 and 853.

Thompson, W. A., and Gaisford, W. F. (1935). Brit. med. J., 2, 1037.

Thomson, J. (1921). Edinb. med. J., 26, 1.

Wallgren, A. (1937). Mschr. Kinderheilk., 68, 290. (1941). Amer. J. Dis. Child., 62, 751.

Ward-McQuaid, J. N., and Porritt, B. E. (1950). Lancet, 1, 201. 